\title{
Excavatory Cycle of Leposternon microcephalum Wagler, 1824 (Reptilia, Amphisbaenia)
}

\author{
Ciclo Excavatorio de Leposternon microcephalum Wagler, 1824 (Reptilia, Amphisbaenia) \\ *,***José Duarte de Barros-Filho; *Leandro dos Santos Lima Hohl \& *Oscar Rocha-Barbosa
}

BARROS-FILHO, J. D.; HOHL, L. S. L. \& ROCHA-BARBOSA, O. Excavatory cycle of Leposternon microcephalum Wagler, 1824 (Reptilia, Amphisbaenia). Int. J. Morphol., 26(2):411-414, 2008.

SUMMARY: The excavatory movements of the spade-snouted amphisbaenid Leposternon microcephalum (Reptilia, Squamata) was studied with the aid of videofluorscopy (X-ray) techniques. This allows the observation of skull and column movements along tunneling, and a more detailed motion observation, being so a novel approach for amphisbaenian excavatory researches. A single specimen of Leposternon microcephalum was kept in a glass terrarium filled with semoline, and filmed with a scopy (X-ray) machine. Fixed anatomical marks on the head of the specimen were put in drawings from the framed recordings. Selected sequences of the recordings were fragmented in isolated frames for motion observation. The analysis of the recordings revealed a repetitive pattern of excavatory cycles, with retreating and downward bending of the head before its upstroke to compact the substrate tunnel roof. Follows a dropping of the head, which lays over the substrate giving support for the next retreating and downward head bending. This is an essential step that was neglected in earlier cycle descriptions. The initial downward head bending was not previously properly described for spade-snouted amphisbaenians. The excavatory movements of spade-snouted amphisbaenians are usually treated as a two-stepped cycle, but the evidence that this excavatory cycle has three steps is given here.

KEY WORDS: Reptilia; Amphisbaenia; Leposternon microcephalum; Scopy; Locomotion.

\section{INTRODUCTION}

The Amphisbaenia are a sub-order of Squamata, characterized by fossorial habits, absence of limbs (except for Bipes) elongated body, and a unique ring-like arrangement of body scale rows (Gans, 1978). Tunnel excavation patterns vary according to the different head morphologies. The most specialized spade-snouted shape is shared by Rhineura, Dalophia, Monopeltis and the South-American Leposternon (Gans, 1974). The sequence of excavatory movements for spade-snouted tunneling was observed by Kaiser (1955), Leposternon microcephalum, visual observations; Gans (1960) Rhineura floridana, visual observations and theoretical analysis with a morphological basis and Navas et al. (2004) L. microcephalum, filming of external body motion. Also, Gans (1974) provided a detailed review of amphisbaenian excavation patterns. The sequence of spade-snouted excavatory movements was described in those articles as a two-step cycle.

However, a novel recording technique with videofluoroscopy (X-rays), here utilized, shows a different picture. The scopy technique allows direct observations of skull and vertebral column movements and of detailed positioning of different body regions. The aim of the present work is to offer a more accurate description of the L. microcephalum excavatory cycle, utilizing the scopy approach.

\section{MATERIAL AND METHOD}

A single specimen of $L$. microcephalum was kept in a glass terrarium $50 \times 35 \times 2.5 \mathrm{~cm}$ (length, height, width), filled with semoline, a granulate nonradiopaque cooking ingredient. The animal was marked with three small lead pieces (tip of snout, mid-ventral chin region and top of head). A fixed camera of a Futuralix videofluoroscopy machine, housed at Santa Casa da Misericórdia do Rio de Janeiro, recorded the amphisbaenian tunneling movements inside the terrarium. Fourteen recordings of complete excavation cycles were selected. The images were framed for movement observation and for drawing movement steps.

\footnotetext{
* LAZOVERTE - Laboratório de Zoologia de Vertebrados - Tetrapoda, Departamento de Zoologia, IBRAG, Universidade do Estado do Rio de Janeiro.

** Laboratório de Anfíbios e Répteis, Universidade Federal do Rio de Janeiro.

Financial support: FAPERJ (Process E-26/170.654/04).
} 


\section{RESULTS}

Fig. 1 illustrates the sequence and mode of movements. Each excavation cycle is composed of: 1) an initial static position with the chin portion of the head and anterior body region lying over the tunnel floor; 2) a retreat and downward bending of the head, with tip of snout touching the floor substrate; 3 ) a continuous upward and forward head movement, which compacts the substrate granules against the tunnel roof. This is followed by dropping of the head, returning to the initial static position. The skull rotates up and down around the atlas-axis joint, and the anterior body vertebrae describe a sigmoid pattern, alternating the supporting contact points with the substrate along the excavation cycle.

\section{DISCUSSION}

The present results are in general agreement with the earlier more important descriptions of spade-snouted amphisbaenid excavatory behavior (Kaiser; Gans, 1960, 1974; Navas et al.). However, the novel use of scopy images provides great observation detail, and hence some important differences were found. Beyond the exact positioning of skull and vertebrae along the excavatory cycle, the initial retreat and downward bending of head was not reported for Rhineura (Gans, 1960). This is striking, considering that this seems to be a vital step, since it is responsible for gaining the necessary momentum for the posterior upward head stroke.

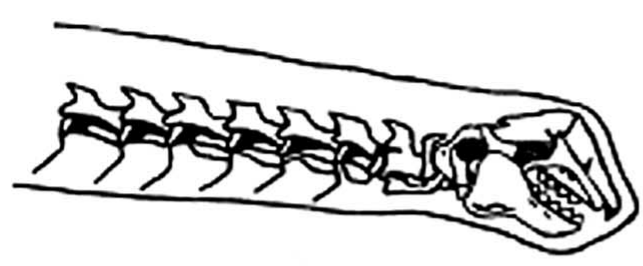

A

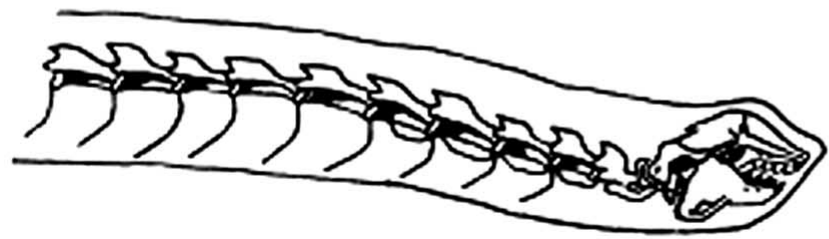

$\mathrm{C}$
Also, the single upstroke step observed here was described as a kind of biphasic motion by Navas et al. for $L$. microcephalum. These authors reported it as initially detaching soil particles and then compacting the granules against the tunnel roof. A similar description was given by Gans (1960) for the first step in Rhineura's excavation cycle, i.e., the penetrating stroke into the soil before the upward head movement. However, the first step in Navas et al. is the same downward bending of the head here recorded.

Maybe the different substrates utilized in earlier works (soil instead of semoline), and the different genus in the case of Rhineura, can account for the diverging results. In fact, Leposternon is considered one of the most specialized amphisbaenids (Gans, 1968), even among the spade-snouted species (Gans, 1977). But most likely the earlier, less refined technical approaches are responsible for the divergences. The initial retreat and bending head movement is indeed somewhat difficult to observe, even with the use of scopy recordings.

The dropping of the head, returning to the static position, is a step that has not been recognized in the literature as of essential value for the excavation cycle, and hence this cycle was considered as a two- and not as a three-step cycle. But without the "static" step, the forces exerted by the amphisbaenian head and body against the soil would lack the necessary mechanical base. In fact, static positioning is a necessary "movement" of the cycle and an integral part of it. If it is not given due importance, one is led to the absurd

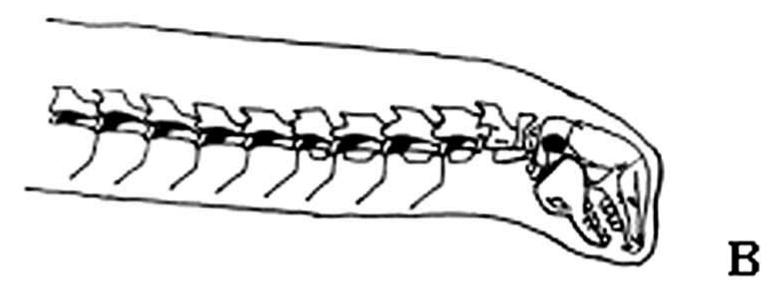

B

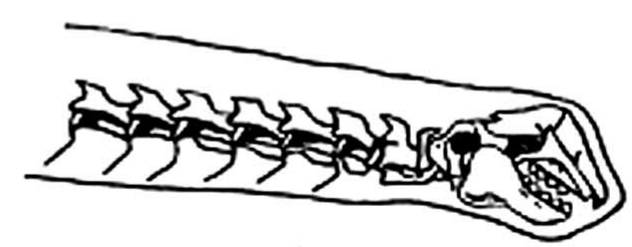

D

Fig. 1. Tunneling of Leposternon microcephalum: A) initial static position; B) retreat and downward bending of the head; C) upward and forward head movement; D) dropping of the head, returning to the initial static position. 
assumption that the initial head bending and the following upward stroke are a single continuous movement, and that amphisbaenian musculature is capable of extraordinary strength, able to maintain continuous up and down strokes of hard-soil compacting without gaining any momentum.

A morphological aspect that needs to be emphasized is the folding of the thin gular skin, during the retreat and downward bending of the head. Gans (1960) discussed the role of skin in the excavatory movements, but only for the gular region, especially the stretching in penetrating and upward strokes. Nevertheless, the close folding of the gular region is as morphologically remarkable as its stretching, otherwise the fundamental initial head bending would not be possible.

The present data, supported by the more accurate scopy recording technique, characterize the excavatory cycle of $L$. microcephalum as a three-step cycle. Besides specific differences among the spade-snouted amphisbaenids, it is likely that this type of cycle is the same for all of those species, the shovel shape of the head apparently being a strong enough convergence to warrant this assumption (cf. Gans, 1974). New scopy recordings of the amphisbaenian excavation cycle are needed for future comparisons.

\section{AKNOWLEGEMENTS}

The authors thanks Dr. Tiago Koch, head of X-Ray Department of Santa Casa da Misericórdia do Rio de Janeiro, who made the scopy images; Msc. Maria Alexandra P. L. Gonçalves, Msc. Flávia Vieira de Oliveira Aguiar and biologist João Vicente Cavalcanti de Camargo (Laboratório de Anfíbios e Répteis - UFRJ), for help with the filming procedures; Msc. Márcia Mocelin and biologist Pedro P. G. Farah (Jardim Zoológico do Rio de Janeiro), for loan of the amphisbaenian exemplar and Humberto Moura-Neto, for help with the English translation. PROCIÊNCIA/UERJ Program. CRBio 02085/84.

BARROS-FILHO, J. D.; HOHL, L. S. L. \& ROCHA-BARBOSA, O. Ciclo excavatorio de Leposternon microcephalum Wagler, 1824 (Reptilia, Amphisbaenia). Int. J. Morphol., 26(2):411-414, 2008.

RESUMEN: Los movimientos excavatorios de la Amphisbaenia (culebrilla ciega), con hocico en forma de pala, Leposternon microcephalum (Reptilia: Squamata) se estudiaron con la ayuda de técnicas de videofluoroscopía (rayos X). Esto permite la observación de los movimientos del cráneo y columna, a lo largo de túneles, y una propuesta más detallada, siendo un enfoque novedoso para investigaciones de la culebrilla ciega excavadora. Un solo especimen de Leposternon microcephalum se mantuvo en un terrario de vidrio lleno de semolina, y fue filmado con una máquina de escopía (rayos X). Se fijaron marcas anatómicas en la cabeza de éste y luego fueron dibujadas desde las grabaciones. Las secuencias seleccionadas de las grabaciones fueron fragmentadas en fotogramas aislados de la observación del movimiento. Los análisis de las grabaciones revelaron un patrón repetitivo de ciclos excavatorios, con la retirada y doblamiento hacia abajo de la cabeza, antes de su movimiento hacia arriba para compactar el sustrato del techo del túnel. Sigue una caida de la cabeza, que se pone sobre el apoyo del sustrato para la próxima retirada y doblamiento hacia abajo de la cabeza. Esto es un paso esencial que es descuidado en las descripciones anteriores del ciclo. La primera flexión baja de la cabeza no fue debidamente descrita anteriormente para Amphisbaenia con hocico en forma de pala. Los movimientos excavatorios de estos animales suelen ser tratados como un período de dos ciclos intensificados, pero la evidencia que este ciclo excavatorio consta de tres pasos, se dan aquí.

PALABRAS CLAVE: Reptilia; Amphisbaenia; Leposternon microcephalum; Escopia; Locomoción.

\section{REFERENCES}

Gans, C. Biomechanics: an Approach to Vertebrate Biology. Philadelphia, J. B. Lippincott, 1974.

Gans, C. Relative success of divergent pathways in amphisbaenian specialization. Am. Nat., 102(926):345$62,1968$.

Gans, C. Studies on amphisbaenids (Amphisbaenia, Reptilia). 1. A taxonomic revision of the Trogonophinae and a functional interpretation of the amphisbaenid adaptive pattern. Bull. Am. Mus. Nat. Hist., 119(3):129204, 1960.

Gans, C. The biological roles of taxonomic characteristics utilised in amphisbaenian classification. British $\mathrm{J}$. Herpet., 5(8):611-5, 1977.

Gans, C. The characteristics and affinities of the 
BARROS-FILHO, J. D.; HOHL, L. S. L. \& ROCHA-BARBOSA, O. Excavatory cycle of Leposternon microcephalum Wagler, 1824 (Reptilia, Amphisbaenia) Int. J. Morphol., 26(2):411-414, 2008

Amphisbaenia. Trans. Zool. Soc. Lond, 34(4):353-416, 1978.

Kaiser, P. Über die Fortbewegungsweise der Doppelschleichen - beobachtungen an Leposternon microcephalus (Wagl.). Zool. Anz., 154:61-9, 1955.

Navas, C. A.; Antoniazzi, M. M.; Carvalho, J. E.; ChauiBerlink, J. G.; James, R. S.; Jared, C.; Kohlsdorf, T.; Pai-Silva, M. D. \& Wilson, R. S. Morphological and physiological specialization for digging in amphisbaenians, an ancient lineage of fossorial vertebrates. J. Exp. Biol., 207(14):2433-41, 2004.
Correspondence to:

Oscar Rocha-Barbosa, Ph.D.

Universidade do Estado do Rio de Janeiro

LAZOVERTE -

Laboratório de Zoologia de Vertebrados -Tetrapoda PHLC sl. 522a - Departamento de Zoologia, IBRAG

Rua São Francisco Xavier, 524 Maracanã CEP 20550-013

Rio de Janeiro, RJ

BRASIL

Received: 14-11-2007

Accepted: 21-01-2008 